\title{
数種の砂の動弾性常数と動内部摩擦係数
}

\section{正員大原資 生* \\ DETERMINATION OF ELASTIC CONSTANTS OF SANDS ON THE VARIABLE CONFINING PRESSURES}

By Sukeo Ōhara, C.E. Member.

Synopsis: The dynamic moduli of Elasticity of Sand are indispensable to the calculation of the Seismic Earth Pressure on the Quay Wall.

Thereat, the auther has measured them by the resonance method changing the Confining Pressure of Sands.

As a result, the dynamic moduli of Elasticity of Sands increase in simple proportion to the Confining Pressure.

Also, the Elastic wave velocity of ground where the sand has been taken, corresponds with the Velocity, calculated by the above Moduli.

In conclusion, the Elastic Constants of the back filling increase in proportion to the depth.

\section{1. 緒言}

筆者は先に, この測定法とその結果の一部を発表したが1), その後, 装置の欠点を改善し数種の砂とついて測定 を行なうとともに，今回はその内部摩擦係数をる求めたので，その結果を総括して述へ，あわせて試料採取地船 の弾性波速度と比較した結果について述べる。

\section{2. 装置および試料}

装置の概略とついては 図一1 そ示す。三軸圧縮試験用のゴムスリーブの中に詰められた径 $7 \mathrm{~cm}$ の砂柱をそれ ぞれの振動板上そつくり，これに縦特よびねじり振動を与えて，強制振動 数を連続的に変化して砂柱が共振状態となつた時の周波数を測定し，これ より弾性常数を知る方法で俗に共振法と呼ばれる方法である。

それぞれの振動板につけられた可動コイル C-R に発振器の出力を導く ことにより, 縦振動では振動板は上下に振動し，また，ねじり振動では可 動コイルは回転自由な円板の腕木の先てつけられているので, 円板は回転 振動を起こす。これらの振動がそれぞれの振動板上の砂柱飞縱むよびねじ り振動を与える。

砂のような粒状体では, その拘束圧力の状態により, その弾性常数が変 化すると云われているので，このことをたしかめるために試料内の空気を

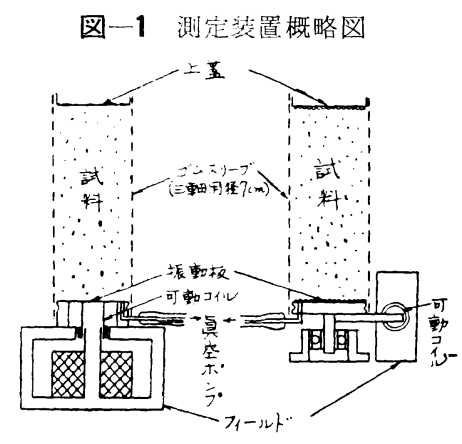
真空ポンプで排除することにより試料沈かる応力状態（側圧）を変化せ しめ, その圧力值は水銀柱圧力計飞よつて測定した。

共振状態およびその周波数の測定には試料の上蓋上飞ロッシェル塩ピッアップを接触させ，その出力をブラウ ン管オシロの垂直変位端子に入れ, 水平変位端子には標準発振器の出力を導いておく。かくして, C-R 発振器の 出力の周波数を連続的に変えてゆき, 垂直変位が最大となつた時, 水平変位とかみ合せてリサージュの図を描か せるととにより共振周波数 $f_{L}, f_{T}$ を求めた。

この場合, 垂直変位が最大となつた時, 上蓋上のピックアップを砂柱の周辺に沿つて上下させ, 砂柱がその長 さの $1 / 2$ 点が節となつている共振状態にあることを確かめて測定を行なつた。

なお，上蓋はその重量をできるだけ軽くして集中荷重とならないように薄いブリキ板を用いてつくつた。

また，ねじり振動では振動板括よび上蓋の表面にサンドペーパーを張つて砂との接触をよくした。

測定結果に対するゴムスリーブの影響は明確にはわからないが，寒天の棒をつくり，これにゴムスリーブをか けて測定を行なつた結果, 試料の長さが縦振動では $13 \mathrm{~cm}$ 以上, ねじり振動では $6 \mathrm{~cm}$ 以上であれぼほとんど影 
響がないという結果を得，径に比して長さがあまり短いと， $f_{L}, f_{T}$ そこの影響が入ることを考えて砂柱の長さは 大体，径の 2 倍，もしくはとれ以上とした。

試料は 表一1 に掲げた四種で気乾の状態で測定した。

それぞれの粒度は 図一2 と示す。

表一1

\begin{tabular}{|c|c|c|c|c|}
\hline 称 & 真 比 重 & 見掛比重 & 間ゲキ比 & 均 等 係数 \\
\hline 新宮浜砂 & 2.65 & 1.48 & 0.78 & 5.00 \\
\hline 博多港 砂 & 2.64 & 1.52 & 0.74 & 5.00 \\
\hline 相 馬 砂 & 2.65 & 1.67 & 0.58 & 1.25 \\
\hline 室見川玉砂利 & 2.63 & 1.55 & 0.70 & 1.32 \\
\hline
\end{tabular}

注）博多港砂の含水比 $3 \%$ のときの間ゲキ比は 0.77
図一2 試料粒度曲線

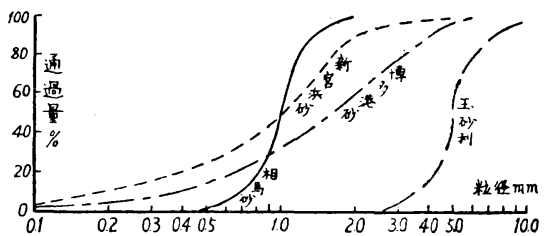

3. 計 算 式

この場合の砂柱の振動方程式はヤング率 $E$, 剛性率 $G$, 縦招よびねじり振動に対する動内部摩擦係数を $\xi_{L}, \xi_{T} T$ とすると，

$$
\begin{aligned}
& \rho \frac{\partial^{2} u}{\partial t^{2}}=E \frac{\partial^{2} u}{\partial z^{2}}+\xi_{L} \frac{\partial^{3} u}{\partial z^{2} \cdot \partial t} \text { (縦振動) } \\
& \rho \frac{\partial^{2} \theta}{\partial t^{2}}=G \frac{\partial^{2} \theta}{\partial z^{2}}+\xi_{T} \frac{\partial^{3} \theta}{\partial z^{2} \cdot \partial t} \quad \text { (ねじり振動) }
\end{aligned}
$$

これより，両端自由の場合の解を求め $f_{L}$ と $E, \xi_{L}$ 抽よび $f_{T}$ と $G, \xi_{T}$ の関係を求めると, 次の通りである。

$$
\begin{aligned}
& 4 \pi^{2} f_{L}^{2}=\frac{E}{\rho}\left(\frac{\pi}{l}\right)^{2}-\frac{\xi_{L}{ }^{2}}{4 \rho^{2}}\left(\frac{\pi}{l}\right)^{4} . \\
& 4 \pi^{2} f_{T^{2}}=\frac{G}{\rho}\left(\frac{\pi}{l}\right)^{2}-\frac{\xi T^{2}}{4 \rho^{2}}\left(\frac{\pi}{l}\right)^{4} .
\end{aligned}
$$

ただし $l$; 砂柱長, $\rho$; 見掛密度

由えに $l$ を変化して $f_{L}, f_{T}$ の測定を行えば (3) 式より $E, \xi_{L} ，(4)$ 式より $G, \xi_{T}$ を実験的求めることがで きる。この場合の $\rho$ は砂柱の重量を容積で除して求めた。

\section{4. 测定結果}

側圧は $0.05 \mathrm{~kg} / \mathrm{cm}^{2}$ から最大 $0.8 \mathrm{~kg} / \mathrm{cm}^{2}$ までの範囲で大体 $0.1 \mathrm{~kg} / \mathrm{cm}^{2}$ ごとに変化して， $f_{L}, f_{T}$ を測定した。

図一3 がその結果であるが，これは同一の砂柱について側圧を 3 回上下させてくり返し測定したときの平均値 である。これより (3)，(4) 式を用いて $E, \xi_{L}, G, \xi_{T}$ を求めると 図一4，5 のようとなる。

図一3 $f_{L}$ の測定結果

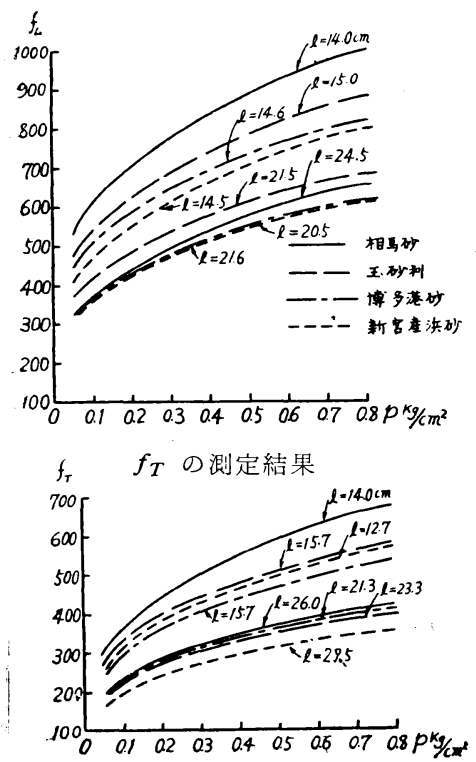

図一4 $E, G$ と $p$ との関係

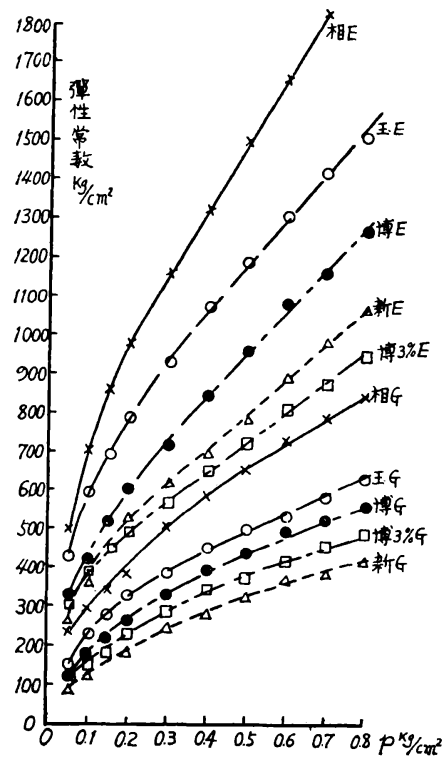

図一5 $\xi_{L}, \xi_{T}$ と

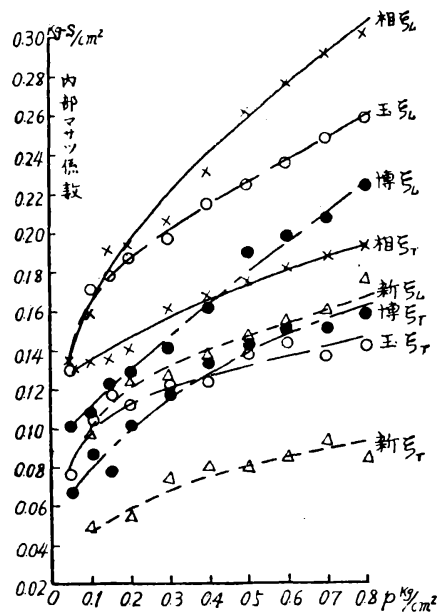


これをみると, いずれの試料でも側圧 $0.2 \sim 0.3 \mathrm{~kg} / \mathrm{cm}^{2}$ 以上では弾性常数は側圧 $p$ 亿直線的に比例して増大す ることが明らかである。

また，内部摩擦係数でもいく分バラツキが目立つが，同様な傾向がみられる。

図一6 は 図-4 の結果よりポアソン比ンを求めた結果であるが, いずれの試料て招いても，側圧の小さいとこ ろでポアソン比は 0.5 亿近く, 側圧の増大と共に漸次減少して一定值になる傾向がみられる。

図一4の側圧 $p$ が $0.2 \mathrm{~kg} / \mathrm{cm}^{2}$. 以上の直線部分飞怙ける $E$ 扎よび $G$ と $p$ との関係を数式で表わすと次のようになる。

相 馬 砂; $E=650+1683 p, G=300+660 p$

玉 砂 利; $E=600=1180 p, G=230+520 p$

博多港砂; $E=400+1120 p, G=200+460 p$

新宮浜砂; $E=350+880 p, G=130 \div 380 p$

\section{5. 室内実験に対する考察}

装置を簡単にするため, 拘束応力状態を変えるに試料内部を負圧とする方法

図一6 $\nu$ と $\boldsymbol{p}$ との関係

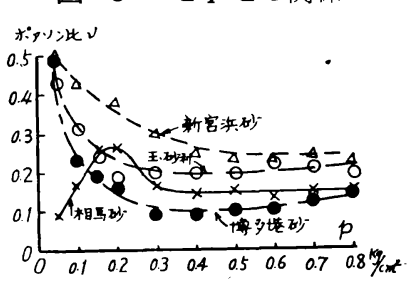

を用いたため, 大気圧以上の応力状態での弾性常数の変化は測定できなかつたが，側圧 $0.05 \sim 0.8 \mathrm{~kg} / \mathrm{cm}^{2}$ の範 囲では砂のような粒状体の弾性常数は, その応力状態によつて異なり, ことに側圧 $0.2 \mathrm{~kg} / \mathrm{cm}^{2}$ 以上では側圧に比 例して直線的に増大すると云う結果を得た。このことは Boussinesqu によつて考劣られた砂の応力ーヒズミの関 係 ${ }^{2}$ 《一致する。

また $\xi_{L}, \xi_{T}$ の值は $10^{-2} \sim 10^{-1} \mathrm{~kg}-\mathrm{s} / \mathrm{cm}^{2}$ 程度で, 側圧との関係は $E, G$ の場合と大体に同じで, 側圧が大と なれば $\xi_{L}, \xi_{T}$ も大となる。

このような測定では，長さを多く変化しての測定結果より最小自乗法を用いて最確值を求めることが望ましい のであるが，装置の関係上余り長い砂柱をつくることができなかつた。本結果は長さ約 $20 \mathrm{~cm}$, 括よび $15 \mathrm{~cm} \mathrm{の}$ 二つの場合の測定によつて求めたものである。

この測定時に砂の間ゲキ比が変ると，その弾性常数が変ることを知つたので，測定は砂の間ゲキ比がほぼ 表一 1 にかかげる程度で行なつた。

また含水比については装置が試料内を負圧とするため，試料の含水比を広範囲に変えての測定はできないが， ただ博多港砂について含水比 $3 \%$ としたときの $E, G$, を求めたので，これを図一4 と一緒に図示したが，その 值は乾燥時より小さくなつている。しかし，この時の間ゲキ比は $0.77 て ゙$ て乾燥時より大きい。

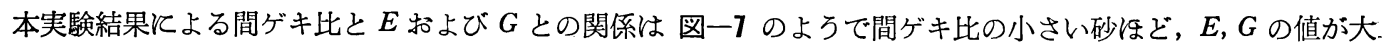
きくなつていることがわかる。図中間ゲキ比 0.77 の点は含水比 $3 \%$ の博多港砂の值で, これが他の点から非常にはずれた值となつていな いこと, 拉よび後述の現地実験結果とを考兄ると, 砂の $E, G$ の値は ほぼ間ゲキ比によつて定まり，含水比には余り影響されないのではな いかと思われるが, この点については今後研究して結論を出したい。

\section{6. 現地実験との比較}

上記室内実験による測定結果と現地盤との対応を知るために試料採 取地の一つである博多港埋立地*で埋立後余り荒らされていない場所

図一7間ゲキ比 $e$ と $E$ 招よび $G$ $\left(\boldsymbol{p}=0.5 \mathrm{~kg} / \mathrm{cm}^{2}\right.$ 飞扮ける) との関係

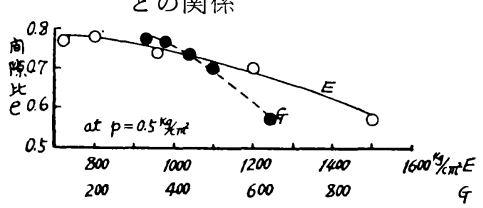

を選んで, コンクリートブロックの落下による起震で地盤の弹性波速度を求めた。現地は昭和 27 年にしゆんせ つを行つた地盤で旧海底は地表下 $7.0 \mathrm{~m}$ で岸壁より約 $40 \mathrm{~m}$ の距離に岸壁に平行に測線を設けた。測線長は $22 \mathrm{~m}$ で可動線輪型振動計 2 コを使用し記録は電磁オシロとより行なつた。

な括, この地盤の現場乾燥密度**は地表下約 $30 \mathrm{~cm}$ ところで平均 $1.56 \mathrm{~g} / \mathrm{cm}^{3}$, 含水比は平均 $8.6 \%$ であつ た。この砂の真比重 2.64 を用いてこの場合の間ゲキ比を求めると 0.69 で室内実験の場合よりやや小さい。

起震に用いたブロックは径 $15 \mathrm{~cm}$, 長さ $30 \mathrm{~cm}$ の丸棒でこれを人力によつて持上げて落下した。

地盤に落下したとき，すなわち発震時刻をオシロに同時記録するには，外部からの振動を避けるため，実験を 深夜に行なうので操作が簡単でしかも確実であることを前提として二，三の方法を考劣，その捛の拓のについて ブロック落下点に近接して振動計を招き，時間の遅れ，確実度等を試験した結果，図一8のような接点をブロッ クに取りつけ，落下の衝撃により(2)金属片が(1)の金属片からはずれて電流が切れると云う方法を採用した。

この方法による時間の遅れはゴムヒモの張力を金属片(2)を支え得る程度にゆるくし, ブロック落下高が $1 \mathrm{~m}$ 以 
図一8 発震時刻用電気 接点略図

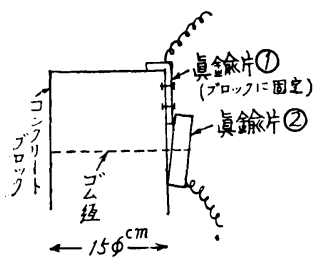

図一9 振動記録

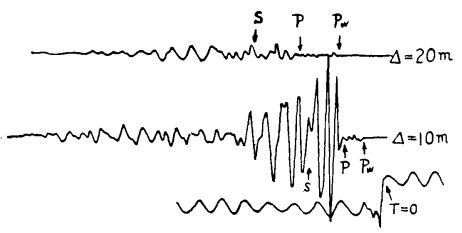

$0.1 \mathrm{sec}$

図一10 走時曲線

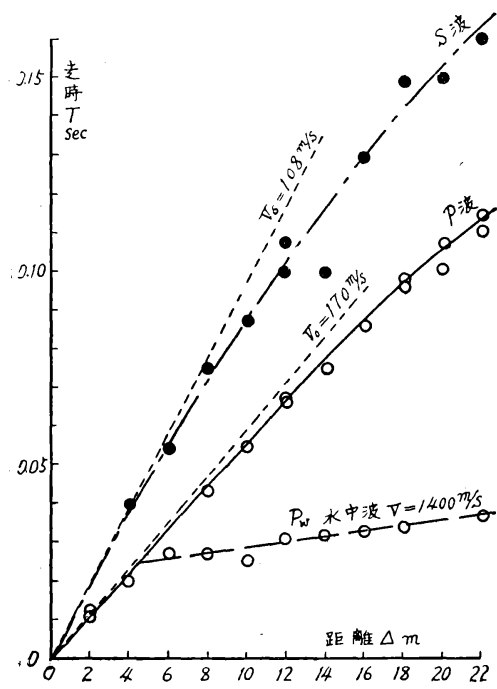

上であればほとんどない。*な挌振動計は 2 コであるので, 両者の間隔 $10 \mathrm{~m}$ として 測線上を同時に $2 \mathrm{~m}$ ずつ移動させて起震をくり返して測定を行なつた。このため走 時曲線に幾分のバラツキがあると考㝋実験を数回くり返した。

この際の記録の代表的なるのを示すと 図一9 のと扮りである。この記録よりとれ ぞれの波の走時を求めたのが 図一10 である。 $P w$ は $P$ と $\Delta=4 \mathrm{~m}$ 付近より分かれた 枝線となつて打り，その速度は約 $1400 \mathrm{~m} / \mathrm{s}$ 程度であるので，これは地下水中を厷わ つた波と推定される。その深さを求めると約 $1.7 \mathrm{~m}$ となり, 実験時の岸壁前面の潮 位（地表下 $2.05 \mathrm{~m}$ ）とほぼ一致する。測線長が短かいため $P$ 波の振幅もかなり大き く, $S$ 波と重なつて $S$ 波の到着が幾分不明瞭となるため, $S$ 波の走 時にバラッキが目立つが，P波， $S$ 波ともにその走時曲線はいずれる $\Delta$ 軸について凸になる傾向が見られる。これは実験前に予想したこと で，いまこの地盤の弾性波速度が $V=V_{0}+k z$ というように深さ $z$ と ともに直線的に変ると考えると, その場合の走時 $T$ は次式 ${ }^{3)}$ で表わ せるためと考兄る。

$$
T=\frac{2}{k} \sinh ^{-1} \frac{k \Delta}{2 V_{0}}
$$

（6）式の地表付近の弾性波速度 $V_{0}$ は $\Delta=0$ そ招ける走時曲線の勾 配の逆数として求められる。

図一10 飞颃いて $V_{0}$ 学求め, (6) 式より $k^{* *}$ を計算すると, この 地盤の波速 $V$ と 深さ $z$ との関係は次のようになる。

$$
\begin{array}{ll}
P \text { 波について } & V=170+16.1 z(\mathrm{~m} / \mathrm{s}) \\
S \text { 波について } & V=108+10.9 z(\mathrm{~m} / \mathrm{s})
\end{array}
$$

一方, 室内実験結果 (5) 式より一応, 側圧 $p$ を地盤の自重による 鉛直荷重 $r_{a} z$ とし, Láme の常数 $\lambda, \mu$ を計算し, 波速と深さとの 関係を定めると近似的*** に

$$
\begin{array}{ll}
P \text { 波について } & V=170+23.0 z(\mathrm{~m} / \mathrm{s}) \\
S \text { 波について } & V=116+13.4 z(\mathrm{~m} / \mathrm{s})
\end{array}
$$

となる。両者を比較するに, 地表速度 $V_{0}$ の值はかなりよく一致し たが， $k$ は余りよい一致をみなかつた。この原因については明確には わからないが，側圧 $p$ を $\gamma_{a} z$ としたことにも問題があると考えられ る。例党ば側圧 $p$ は地盤中の三主灾力の平均值飞相当すると考元, その際の静止土圧係数を 0.5 程度とすると, $p$ 波は $V=170+15.2 z$, $S$ 波は $V=116+8.9 z$ となり現地実験值にかなり近い值となる。乙 かし, 静止土圧係数は土の性質はもち論, 地盤の生成の過程によつても異なると考学られるので, ここでは一応 $r_{a} z$ と考㝋た。

\section{7. 結 語}

以上，室内実験によつて四種の砂の弾性常数を測定した結果，砂の弾性常数はその拘束圧力にほぼ直線的に比 例して増大するということがわかつた。この拘束圧力を地盤の自重と考兄ると, 砂の弹性常数は地盤の深さによ りほぼ直線的に增大寸ると推定される。

このことを確かめるためと武料採取地盤の一つについて弾性波速度の測定を行なつたところ前述の推定を比較 的よく裏づけ得る結果を得たので，ここに報告する。な拉，現地実験結果より，直接その地盤の弾性常数を求め たいと考朰ているので, 現地実験と室内実験との比較について今後とも, 充分研究してみたいと思つている。

この実験は筆者が松尾教授とともに行なつている地震時土圧に関する研究のために行なつたもので， 御指導， 御批判いただいた松尾教授，水野教授に感謝するととるに深夜，現地実験を手伝つてくれた九大助手，松尾博 君, ならびに運輸省博多港工事々務所の方々に厚く謝意を表する。

1）土と基礎： 5 巻 1 号

参考文 献

2) 最上武雄：土質力学（岩波全書）

3) 萩原尊礼: 物理探鉣法

(昭. 32.10.25)

* 記録紙速度 $20 \sim 30 \mathrm{~cm} / \mathrm{s}$ 程度で試験し時間の遅れは見出せなかつた。并* には $v^{0} \sqrt{1+k z}$ の形となるが $z$ を 0 より $7 \mathrm{~m}$ までと限定し近似的に $v_{0}+k z$ を解き得る。 